\title{
Determinants of Zakat Compliance Behavior among Muslims Living Under Non-Islamic Governments
}

\author{
Adamu Ummulkhayr \\ Kogi State College of Education \\ Musa Yusuf Owoyemi \\ Universiti Utara Malaysia \\ Rafidah Binti Mohammed Cusairi \\ Universiti Utara Malaysia
}

\begin{abstract}
Zakat is one of the five pillars of Islam hence it is attracting a lot of scholarly attention. However, most of the existing literature on Zakat are concentrated in Islamic countries like Indonesia, Malaysia, Pakistan, Jordan, Saudi Arabia and others. There are also some researches in some advanced non-Islamic countries such as the USA and UK. In these countries, though the government does not operate Islamic laws, there are organized NGOs that take care of Islamic affairs including Zakat. However, there are many parts of the world where Muslims live under non-Islamic government and are not assisted by NGOs. In those areas, Muslims live and perform their religious obligations without any form of institutional support. There are limited number of research relating to Zakat in those areas. This study seeks to fill this gap by investigating the determinants of Zakat compliance in Kogi State of Nigeria. The study was conducted through qualitative interviews. Findings show that, the absence of governmental or institutional support results in ignorance, lack of organization and attitudinal problems. Recommendations were offered to assist Muslims in such areas.
\end{abstract}

Keywords: Zakat compliance, Muslims in non-Islamic areas, Institutional support for Zakat

\section{INTRODUCTION}

Zakat is one of the pillars of Islam, making it to attract a lot of scholarly attention. Moreover, the attention on Zakat also arises from the fact that it is a sensitive economic issue. It involves the compulsory transfer of a share of one's wealth to the less-privileged. The importance of Zakat is stressed in the Holy Qur'an such that it is often enjoined in association with Salat (Qur'an 74:43-44). The traditions of the prophet equally placed a lot of emphasis on the obligation of Zakat. Numerous scholarly researches have been conducted on Zakat compliance especially on the factors that influence compliance behavior. This is understandable as the level of poverty among the Muslim Ummah remains high (Ahmed, 2004).

Despite numerous previous research efforts on Zakat compliance, the fate of Muslims living under non-Islamic governments has received little scholarly attention. Most of the previous studies on Zakat compliance appear to concentrate on countries where Islam is the dominant and state religion (DeZayas, 2003). Such countries include Indonesia, Malaysia, Pakistan and the Islamic countries of the Middle East. However, it should be noted that the socio-political conditions in these countries are different from countries 
where Islam is not the dominant religion and the laws are not derived from Islamic perspectives. For instance, the constitution in Muslim dominated countries like Malaysia provides legal framework for effective administration of Zakat (Ahmed, 2004). In contrast, the constitution of secular countries such as Nigeria considers Zakat and other religious obligations as a private affair. This means that issues of Zakat do not have any support from government and it is not supported by constitutional laws.

Since Muslims living under nonIslamic governments do not operate under national Islamic laws, it is left for the Muslims to organize their Islamic affairs privately and this constitutes a challenge to the Muslims. In the absence of government support and enabling laws, Muslims living in non-Islamic states are coordinated by Islamic community leaders such as imams and scholars. However, this cannot be as effective as situations where Muslims are supervised by Islamic governments. Even in the time of the prophet, affairs of Zakat were coordinated and supervised centrally by the prophet (De Zayas, 2003). This was also the situation after the demise of the prophet. For instance, it was reported that Sayyidina Abu-Bakr (R.A) used the authority of the Islamic caliphate to enforce Zakat compliance among the Ummah (Al-Qardawi, 1999; Bonner, 2003; Mattson, 2003; Nanji, 1985). To underscore the importance of enforcing Zakat compliance by the authorities, AbuBakr (R.A) responded to Umar (R.A), who warned him against waging war with fellow Muslims, in the following manner:

\footnotetext{
By Allah, I will fight those who differentiate between Assalat (the prayer) and the Zakat, as Zakat is the compulsory right to be taken from the property (according to Allah's orders). By Allah, if they refuse to pay me even a she-kid which they used to
}

\begin{abstract}
pay at the time of Allah's messenger, I will fight with them for withholding it. Then Umar said "By Allah, it was nothing, but Allah opened Abu-Bakr's chest towards the decision (to fight) and I came to know that his decision was right" (Sahih Bukhari, Hadith No.1, 400, p.270).
\end{abstract}

The administration of Zakat by the Islamic government continued under Umar (R.A) and other caliphs after him. In contemporary times, the administration of Zakat by governments have continued in many countries that are practicing Islamic system and some scholars have argued that it is the responsibility of government (Abdullah \& Suhaib, 2011; Abd-Wahab \& Abdul-Rahman, 2011; De-Zayas, 2003; Singer, 2013). As argued by scholars (Ahmed, 2004; Ashafa, 2014; De-Zayas, 2003), when Zakat is left to individuals to manage without the support of government, it does not perform optimally.

This study investigates the situation of Zakat compliance in countries that are not governed by Islamic governments. There are some questions of interest in this study. Firstly, since government laws in secular countries do not cover Zakat, how do Muslims organize their Zakat matters on their own in such countries? Secondly, what are the challenges faced by Muslims living in such countries in trying to fulfill the religious obligation of Zakat? These questions are important because the absence of governmental support makes Zakat administration prone to peculiar challenges in such societies. Unlike the Islamic countries where governmental powers are used to collect and distribute Zakat, Muslims living under non-Islamic governments will need more of voluntary compliance.

Voluntary compliance means people have to comply on their own without being compelled. However, it is 
difficult to achieve voluntary compliance in the absence of government authority. As noted earlier, the caliphs after the prophet used the coercive powers of government to collect and distribute Zakat in the early days of Islam (Al-Qardawi, 1999; Bonner, 2003; Mattson, 2003, Nanji, 1985). Additionally, how will the Islamic community under non-Islamic governments organize their Zakat affairs in terms of collection and distribution? How will they arrange the hierarchy of authority in the absence of government powers? These are fundamental questions that should be addressed in trying to understand Zakat compliance among Muslims in non-Islamic countries.

This study aims at addressing the issues raised above through a qualitative study. Interviews were conducted with Zakat stakeholders in the Nigerian state of Kogi in order to gain insight into the issues and challenges of Zakat compliance among Muslims living under non-Islamic governments. The study proceeds as follows: section two presents an overview of the literature on Zakat. Section three presents the methodology adopted by the study to find answers to the research questions. Section four presents the result and discussion, while section five concludes the study.

\section{LITERATURE REVIEW}

Zakat is the third pillar of Islam coming next to Salat in the hierarchy of the five pillars of Islam. According to Benthall (1999), Zakat is derived from the rootword 'Zaka' which means to purify. Purification in the sense that it cleanses the giver of greed while at the same time cleansing the receiver of jealousy. The giver is satisfied to have fulfilled his religious obligation and assisting a lessprivileged Muslim while the receiver is happy to have been cared for by the richer Muslim. Zakat is meant to be paid annually on wealth that has reached a threshold known as Nisab and should have been in possession of the wealth owner for one year (hal) (Ammani et al, 2014; Dogarawa, 2009; Ram \& Rozani, 2014). It is important to note that Zakat is not only due on cash but encompasses productive assets and valuables such as crops, animals, merchandise, gold and silver (Abdul-Fattah, 2004; Singer, 2009; Islahi, 1993). The importance of Zakat is so much stressed in Islam to the extent that guardians of the wealth of orphaned children and the mentally challenged are obliged to pay Zakat on their behalf.

From the early history of Islam, Zakat was administered by the Islamic authorities in a collective manner. During the era of the prophet (PBUH), Zakat administration was controlled centrally. It was considered a public affair such that Zakat administrators were appointed by the prophet himself (Samad \& Glenn, 2010). The prophet appointed people of integrity who went about assessing people's wealth to determine what was due as Zakat. Zakat funds were not mixed with other state resources because the Qur'an explicitly stipulated the beneficiaries of the funds. The following eight categories of people are qualified to receive Zakat as ordained by Allah (SWT) in the Holy Qur'an:

As-Sadaqaat (meaning
Zakaat) are only for the
fuqaraa (poor) and Al-
Masaakin (the poor), those
employed to collect (the
fund) and to attract the
hearts of those who have
been inclined (towards
Islam), and to free the
captives, and for those in
debt and for Allah's cause
(i.e.for Mujahiduun-those
who fight in a holy battle),
and for the wayfarer (a
traveler who is cut off from
everything); a duty imposed
by Allah. And Allah is all-


Knower, all-Wise (Qur'an, 9:60).

Al-fuqaraa (the poor): AbdulFattah (2004) defined the poor as someone who lacks the basic necessities of life which includes food, clothing and shelter. Poverty could result from paucity of means, old age, disability and other conditions. Abubakar \& Abdul-Hakim, (2010) stated that people are considered poor if they do not have a job from which they can earn a living. The authors also contended that people who have the ability to earn a living but are constrained by religious duties are also considered suitable for receiving Zakat.

Al-Masaakin (the needy): There are differences of opinions among scholars on those that could be described as needy. Abdul-Fattah (2004), and Korayem and Mashhour (2014) claimed that the needy is in a worse condition than the poor. According to Ash-Shafi'i, the needy is someone who does not have enough to cater for his needs. Other scholars contended that the needy are people who possess nothing (De Zayas, 2003; Yusuf, 1990). However, the prophet's (PBUH) position on the person that could be termed needy is unambiguous. He stated that the needy is someone who does not ask for assistance from people due to modesty (Sahih-Al-Bukhari, 2, 557). However, the dividing line between the poor and needy is not well pronounced. Both are usually classified as people who lack the means to sustain themselves. Such people include orphans, widows, students, old people, the sick, and very low income earners (Adebayo, 2011; Kochuyt, 2009).

Al-Aamileena Alayhaa (the Zakat administrator): These are the people selected by the authorities to administer Zakat in terms of assessment, collection and distribution (Abubakar \& Abd-Ghani, 2011). The administrators are entitled to part of the proceeds of Zakat as compensation for their effort (Abd-Fattah, 2004).
Al-Muallafati quluubuhum (those whose hearts are inclined): This category of people includes those that are given Zakat to make Islam attractive to them. Others in this category are converts whose faiths are still weak and those given Zakat to avoid their evil plans against the Muslims (Abdul-Fattah, 2004; Abubakar \& Abd-Ghani, 2011; Al-Qardawi, 1999; Maududi, 1984). However, Abdu-Fattah (2010) reported that imams Malik, AbuHanifah and Ash-Shafi'i contended that this category of Zakat recipients should no longer be accommodated as Islam is already established and no longer requires wooing of converts. In contrast to the opinion of the imams, Abdul-Fattah (2010) argued that many Muslims still harbor weak faiths and need to be placed on Zakat in order to strengthen their iman.

Fee-Rriqaab (to free slaves): There is a consensus among scholars that the practice of slavery has ceased worldwide (Abubakar \& Abd-Ghani, 2011). However, poor Muslims who are oppressed and prevented from practicing their religion could still benefit from this category of Zakat (Al-Qardawi, 1999).

Fee-Sabililah (in the way of Allah): Scholars are unanimous in their opinions that this category of people are those engaged in jihad. Giving them Zakat enables them to obtain basic necessities such as food and clothing (Abdul-Fattah, 2010; Kochuyt, 2009). Some scholars included students among this category (Abdul-Fattah, 2010; Al-Qardawi, 1999; Singer, 2009). Furthermore, Kochuyt (2009) asserted that proceeds from Zakat could be utilized in constructing mosques, schools, hospitals, religious foundations and even to fund relief programs. Though these initiatives are laudable, Abdul-Fattah (2010) argued that Zakat funds should not be invested in such capital projects as the poor and needy may not benefit from them.

Ibn Sabil (the wayfarer): This category of people are those that are on a journey and face the difficulties usually 
associated with travelling. However, as noted by Abdul-Fattah (2010), the journey should not be performed to commit acts of disobedience.

Al-Ghaarimeen (the debtors): This category of Zakat is given to assist debtors in minimizing their debts because debts could prevent the faithful from fulfilling their religious obligations.

\section{Zakat Administration Under Islamic Governments}

Since this study investigates the determinants of Zakat compliance among Muslims living in non-Islamic jurisdictions, this section takes an overview of the literature on Zakat in countries practicing Islamic laws. This will enable comparison with countries where Muslims live under secular laws. In Islamic countries, payment of Zakat is compulsory while some Islamic countries consider it a voluntary affair and do not enforce it strictly. Countries in the first category include Sudan, Malaysia, Libya, Yemen and Saudi-Arabia (Lorenz, 2013; Obaidullah, 2016). In the second category of countries, though Zakat is supported by official law, it is left to the discretion of the individual Muslims. Countries in this category are Bahrain, Bangladesh, Egypt, Indonesia, Iran, Jordan, Kuwait, Lebanon, and United Arab Emirates (Hashem \& Shaier, 2015; Lorenz, 2013).

In Indonesia, the Zakat Act No. 23 of 2011 is enshrined in the constitution. It permits voluntary payment of Zakat and the payer could calculate the amount of Zakat due on his assets personally or engage the services of the Indonesian Zakat Authority, Badan Amil, Zakat National (BAZNAS) (Latief, 2010; Lim, 2015; Obaidullah, 2016; Salim, 2014). In Brunei Darus Salam, Zakat administration is handled by the government through the Islamic Religious Council of Brunei. The council is vested with the power to collect and distribute Zakat funds (Rose, 2010). The council collects applications for Zakat funds from potential recipients, verify claims by the applicants and disburse funds accordingly.

In Malaysia, Zakat matters are given priority by the government. Zakat is currently backed by law and each state in the Malaysian federation is permitted to enact its own laws concerning Zakat. Accordingly, each state has a State Islamic Religious Council (SIRC) which handles the affairs of Zakat in their respective states (Nurul Husna, 2010). The SIRCs are responsible for collection, distribution and other issues pertaining to Zakat administration (Abd-Wahab \& AbdulRahman, 2011; Zainol et al, 2009). Interest in Zakat in Malaysia is divided into three categories: Zakat on business, Zakat on income, and Zakat on savings. Zakat on income is deducted from the salaries of wage earners at source (Zainol et al., 2009) thus making it a compulsory transfer.

Pakistan is another country that has made constitutional provision for the administration of Zakat. According to Shirazi (1996), Zakat was made an official state affair in Pakistan in 1980. Hitherto, it was performed voluntarily and paid directly to the less-privileged among neighbors, relatives and friends (Shirazi, 1996). Currently, Pakistan has a Central Zakat Council and provincial councils in each of the provinces. There are also district Zakat committees and village level committees (Abdullah et al, 2013; Shirazi, 1996). Zakat funds are accumulated centrally by the Central Zakat Council and managed by the State Bank of Pakistan from where it is shared to the provincial councils according to a stipulated proportion (Toor \& Wabir, 2001; Abdullah et al, 2013). Suhaib (2009) asserted that the Zakat system in Pakistan is effective as it has assisted the poor with basic necessities. He stated that it provides special allowances for widows, destitute and the aged and sponsors education of the poor up to university level in some cases. It also provides free healthcare for the lessprivileged (Lorenz, 2013). 
Zakat Administration in Non-Islamic Jurisdictions

Among Muslims living in countries that do not follow Islamic laws, Zakat is performed as a private individual affair and in some cases coordinated by NonGovernmental Organizations (NGOs). Some of the NGOs are global in their operations. For instance, the International Islamic Relief Organization has branches in several countries and channels Zakat funds to areas of need such as natural disasters (Benthall, 1999). In America which is a non-Islamic country, Muslims have the option of paying their Zakat through the Zakat Foundation of America (ZFA) which then distributes proceeds to needy Muslims (ZFA, 2007). The ZFA board consists of scholars and professionals to ensure sound management. In South-Africa which is also a non-Islamic state, Zakat collection and distribution is performed by NonProfit Organizations (NPOs). Singapore has an Islamic organization, Majlis Ugama Islam Singapura (MUIS) which performs the function of Zakat collection and distribution among the Muslim Ummah (Obaidullah, 2016).

Determinants of Zakat Compliance in Islamic and Non-Islamic States - The Nigerian Case

From the review of literature in this section, it is clear that the issue of Zakat is understood from two broad perspectives. These are Zakat under Islamic governments and those under non-Islamic governments where individuals and NGOs perform the function. Consequently, Zakat compliance is bound to be different in these areas. Countries with Islamic governments utilize governmental powers to collect and distribute Zakat as enshrined in their constitutions. For instance, income Zakat is deducted at source from workers in Malaysia (Zainol et Al., 2009). However, in non-Islamic countries, the absence of governmental laws means Zakat compliance is subject to individual discretion and the ability of NGOs to coordinate collection and distribution. In non-Islamic countries, Zakat compliance cannot be as effective as they are in Islamic countries.

Despite the differences identified above, this study highlights a gap in the literature using Nigeria as a case study. There are billions of Muslims worldwide and some Muslims live in areas that are neither under Islamic jurisdiction nor assisted by NGOs in managing their Zakat affairs. Such Muslim communities are usually found in rural and backward areas. Nigeria presents an ideal case for investigating such cases. The country does not operate Islamic law at the federal level; rather, it operates a secular constitution (Olarenwaju, 2014). This is because the country is populated with a mixture of Muslims and Christians such that attempts to use the machinery of government to promote any religious doctrine usually generate controversy (Ostien \& Dekker, 2010). There are 36 states that make up the Federal Republic of Nigeria. States in northern part of the country such as Kano, Bauchi, Sokoto, Kebbi, and Zamfara are predominantly Islamic hence they have local state laws to manage the affairs of Zakat. The south-western part of the country has a mixture of Muslims and Christians. However, the area is largely urbanized with a large population of educated Islamic elites and scholars; hence, NGOs are present, and they assist in managing Zakat affairs. The northcentral part of Nigeria presents a unique case, which constitutes the gap in this study. This part of Nigeria has states that are populated by almost equal proportion of Muslims and Christians. The governments of such states follow the federal law; in other words, they are neither Islamic nor Christian laws. In fact, the laws are secular (Ostien \& Dekker, 2010), leaving matters of religion to private discretion. Unfortunately, this part 
of Nigeria is largely rural and underdeveloped. NGOs are not present, and there is no government support for Zakat administration, thus leaving it entirely to the discretion of individuals and the Muslim community. This is a unique case that is yet to receive adequate attention in the literature. Filling this gap is important because, apart from Nigeria, there could be Muslim communities scattered all over non-Islamic countries of the world facing similar situations.

\section{METHOD}

\section{Research Design}

The study adopted the qualitative methodology in investigating the issues raised by this study. As noted in the problem description, Muslims living under non-Islamic governments and without the assistance of NGOs represent an understudied group. This type of situation calls for exploratory studies that could be performed using the qualitative approach (Creswell, 2013). As noted by Marshall and Rossman (1989), the qualitative approach is more suitable for novel studies where variables are yet to be identified. The choice of the qualitative approach in this study is also in line with Creswell (2013), who stated that the approach is suitable for granting voice to a hitherto unheard group. Moreover, the qualitative approach is used to study a phenomenon about which little is known (Bricki \& Green, 2007; Richard \& Morse, 2013) and when a deep understanding of the issues is required (Merriam, 1988). Based on the position of experts on the qualitative approach as stated above, it appears the method is best for this study.

\section{Population and Area of The Study}

In line with the recommendations of Creswell (2013), the study follows a case study approach. Creswell described a case study as having a clear and distinct boundary. In the case of this study, it is restricted to Kogi State in the central part of Nigeria. There is no official record of the number of Muslims in the state, but anecdotal evidence shows that there is a large population of Muslims living together with Christians in the state. Since the government is not involved in religious affairs, the issue of Zakat in this population is left to the initiative of the Muslim population. The Muslim population, as determined by this study, consists of three distinct groups: the wealthier Muslims, who are the Zakat givers; the poor and needy Muslims, who are the Zakat recipients; and the Islamic leaders/scholars, who provide religious leadership to the entire Islamic community.

\section{Sample and Sampling Procedure}

The study utilized the maximum-variation sampling strategy (Creswell, 2013). This strategy involves selecting participants with different characteristics in order to ensure credibility of the sample. This type of sampling enables the researcher to purposefully select samples from the population based on established criteria, taking cognizance of the diverse nature of the population (Creswell, 2013; Richard \& Morse, 2013). As stated earlier, this study considers the population of Muslims to be divided into Zakat givers, Zakat recipients, and the Islamic scholars/leaders. Hence, the sampling of the study was purposefully performed along those lines. Samples (10 numbers) were selected from the population of the poor people (Zakat recipients). The selection was based on the definition of the poor, as provided in section two. Ten people were also selected from the population of the richer Muslims (Zakat payers). The sample of the Islamic scholars/leaders also consists of 10 selected persons, thus making a total of 30 participants. 
Moreover, there is no specific requirement for sample size in a qualitative study (Richard \& Morse, 2013). Qualitative study could stop further investigation if it gets to a saturation point (Gillham, 2005; Bricki \& Green, 2007). The saturation point is the point at which no new evidence is being added to the existing one.

\section{Data Collection Process}

This study utilized primary data for the study, collected by way of interviews with the participants. Semi-structured interview was used in eliciting responses from the participants since it allows the researcher to be in control of the process (Creswell, 1984). Semi-structured also means that the questions to which responses were sought were predetermined by the researcher, although there was room for flexibility as the interview progressed. Responses at times lead to new questions, and in some cases, new questions were asked as a follow-up to obtained responses.

\section{Method of Data Analysis}

Thematic analysis was utilized to analyze the data from the interview transcripts. The first step was a thorough reading and rereading of the transcript in order to understand the data thoroughly and to enable coding, which was the first task in the analysis (Marshall \& Rossman, 1989). The coding process was started by assigning codes to fragmented words. The process followed recommendations of
Creswell (2014). Firstly, codes were written along the margins of the transcript. The codes were then arranged into categories, revised, and re-written until a satisfactory pattern emerged, as recommended by Yin (2011). The major categories or themes were developed in line with the research objectives, which seek to determine the factors that influence Zakat compliance in a unique case such as the one of Muslims living under nonIslamic governments. Care was taken to grasp the meaning in the data although this does not pose much problem since member checking was done during the interviews to verify the meaning of words that appeared ambiguous.

\section{RESULTS AND DISCUSSION}

The study set out to investigate the determinants of Zakat compliance behavior among Muslims living in nonIslamic territories through interviews with Muslims in the study area. The findings fall into three main themes of ignorance, attitudinal problem, and organizational problem. These themes also have subthemes under them, and there was an overall theme of institutional factors, which appeared to be the main problem triggering the main themes. The conceptual framework of the findings is presented in Figure 1 and the discussion of the findings follows. 


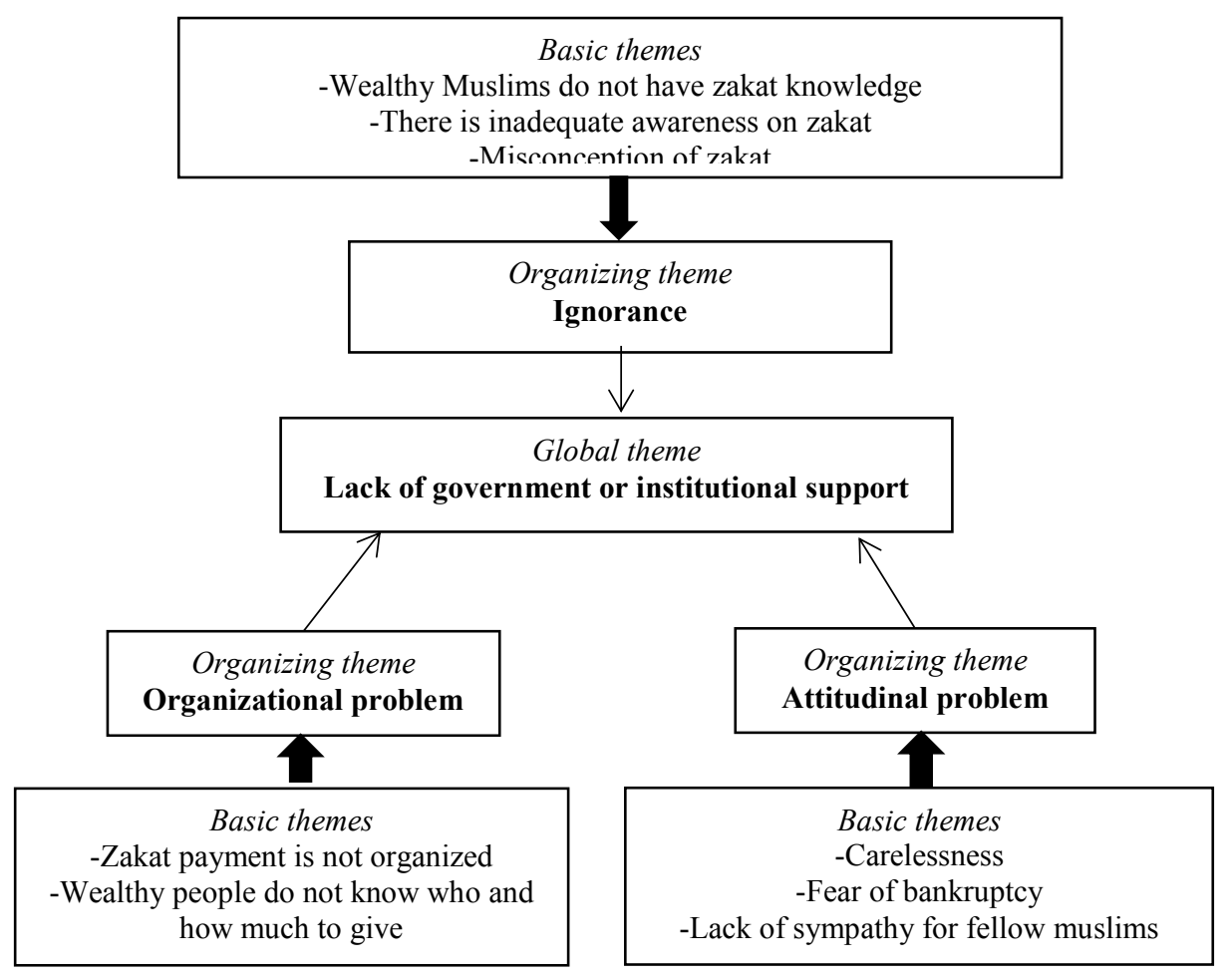

Figure 1 Thematic arrangement of interview findings

\section{Ignorance}

Ignorance of the Islamic religion and the obligatory pillar of Zakat appear to be a major problem among Muslims in the study area. For this reason, even those who are conscious of their religious obligations may not fulfill them appropriately if they do not have adequate knowledge on how to go about them. As noted by participant 15: "maybe because of lack of awareness on the administration of Zakat; in fact, when you come up with the issue of Zakat, people are like; they only know of Zakatul fitr, they cannot differentiate between Zakatul mal and Zakatul fitr." Participant 19 is also of the same view as participant 15:

The Muslim, especially the well-to-do, they don't seem to understand Zakat. They thought Zakat is voluntary. They don't know that they are wealthy, when their wealth is up to what is called nisab, there are obligations on them that Allah has placed on them...the only Zakat they know is Zakatul fitr, the one given at the conclusion of Ramadan fasting... and the sadaqah you give out on your way, when you see beggars.

Participant 19 added that people are not aware of the obligatory nature of Zakat as the third pillar of Islam. They thought when they performed salat, they have fulfilled the most important religious obligations, so other obligations such as Zakat is not necessary. In addition to awareness, the technicalities of paying Zakat require some knowledge of the Shari'ah. The average Muslim, especially in countries that do not have Islamic institutions to enlighten Muslims, do not possess the know-how on paying Zakat. In countries such as Indonesia, Zakat organizations, BAZNAS, engage Muslims in enlightenment campaigns to teach them the doctrines of Islam regarding Zakat 
(Obaidullah, 2016). Where the Muslims live on their own, this institutional awareness creation is lacking. Although the Islamic scholars and leaders do create awareness on Islamic doctrines once in a while, it is not adequate, as stated by another participant. He stated that the Islamic scholars do not emphasize on the Zakat on wealth when they preach, in order not to be seen as intruding into the private lives of the rich people. Moreover, where there are no established institutions to manage a public affair such as Zakat, it is difficult for individual preachers and scholars to manage the situation. Moreover, the individual scholars are private citizens who have their own schedules and jobs to perform.

The findings of this study confirm those reported by previous authors (Ahmed, 2004; Ashafa, 2014; De Zayas, 2003) who argued that when Zakat administration is left to individual discretion, it cannot be as effective as when it is supervised by government. Moreover, according to the framework of the findings of this study (Figure 1), theme one, i.e., ignorance, does not exist alone; it is linked to the main problem, which is lack of institution and attitude problem. In addition to ignorance, as noted above, attitude factors also contribute to Zakat non-compliance among Muslims living under non-Islamic governments. Some Muslims are aware of their Zakat obligation but do not bother paying. In other words, their attitude towards Zakat is that of non-challans. According to participant 11: “...there is no person or government to oppose or challenge them, as was done in Islamic states of the past; acts of impunity becomes the order of the day." Participant 20 spoke in line with participant 11: “...it is ignorance and impunity, nothing will happen. You know, when somebody is daring God because they don't see God...they are daring God that nothing will happen."

Participant 20 emphasized the fact that breaking Allah's laws, such as not paying Zakat, does not lead to immediate consequences in a society where Islamic law does not exist. Since there are no consequences, Muslims with low faith tend to avoid fulfilling their obligations. However, this problem does not exist alone as shown in Figure 1. Where Muslims live under Islamic institutions, there would be no need to wait for Allah's punishment to descend on Muslims who do not comply with Zakat, Islamic governments can take appropriate measures to take Zakat from Muslims. For instance, the case of Malaysia is reported in the literature (Zainol et al., 2009). The Malaysian government deducts income Zakat at source. In a situation similar to that of Malaysia, the government is able to control the attitude problem. However, where Muslims are left on their own, the attitude problem becomes worse.

\section{Organizational problem}

According to some of the participants, especially the Zakat payers, sometimes they would want to give Zakat but do not know who exactly to give. They end up giving whoever is close by or whoever they run into. The problem with leaving Zakat to individuals to pay as they deem fit is such that the whole system is subject to chaos. For instance, payers do not always know exactly who to give. They cannot know who has received from other Zakat givers already. However, in an organized system, there will be records of those that are receiving Zakat and how much they are receiving. Previous studies reported that Zakat applications are verified in Brunei before funds are disbursed to the recipients (Rose, 2010). This is only possible where institutions are involved. Moreover, contemporary Zakat management requires wisdom that can only be applied when Zakat is managed by institutions. Zakat funds are being invested to generate profit and increase the fund available for poverty alleviation as in the case of Brunei (Rose, 2010). All these 
initiatives require modern management, which is absent in areas without Islamic governments and highly organized NGO support. Similar to the previous two themes, the theme of organizational problem is also linked to institutions. The findings of this study have contributed to the numerous literatures on Zakat compliance. The study is unique in the sense that it investigated Zakat in a context different from those reported thus far in literature. This study has brought the problem of Zakat among Muslims living under non-Islamic governments to the fore.

\section{CONCLUSION}

This study was conducted to investigate the problem of Zakat compliance among Muslims living in non-Islamic jurisdictions. Previous studies on Zakat had concentrated on traditional Islamic countries such as Indonesia, Malaysia, and Pakistan. Some states in Nigeria, such as Kogi, where this study was conducted, present a unique challenge in the effort to understand the dynamics of Zakat among Muslims. Being an exploratory study, the study utilized the qualitative approach. The findings point to ignorance, attitude problem, and lack of coordination as the key problems facing the Zakat system. However, in the context investigated, lack of institutional supports was found to be overall theme from which other themes developed.

The solution to the problems of Zakat among Muslims in non-Islamic contexts is not an easy one. Since the countries affected by this type of problem cannot be converted to Islamic countries and their constitutions cannot be amended to accommodate Islamic laws, it is left for Muslims to organize themselves based on the principle of the Islamic faith. Muslims in such areas may not be able to do it alone. Muslims from the more organized Islamic countries should assist their brothers living under non-Islamic governments to organize their religious affairs, especially Zakat. They could do this by setting up Zakat offices for Muslims living in non-Islamic countries and providing assistance in the form of staff and equipment for such offices. This will go a long way to tackling the problem of Zakat in such Islamic societies.

\section{REFERENCES}

Abdullah, M. \& Suhaib, A. (2011). The impact of zakat on social life of Muslim society. Pakistan Journal of Islamic Research, 8, 85-91.

Abd.Wahab, N., \& Abdul Rahman, A. (2011). A framework to analyse the efficiency and governance of zakat institutions. Journal of Islamic Accounting and Business Research, 2(1), $43-62$.

Abdul-Fattah, M.M. (2004). Al-fiqhulmuyassaru minal-Qur'ani was sunnah, (vol. 1). Egypt: Dar alManarah.

Abdullah, Naiz, M., Rashid, A.S. \& Imran. (2013). The role of zakat in improving the economic status of beneficiaries in Khyber Pakhtunkhwa. Journal of Managerial Sciences, 7(2), 243 253.

Abu Bakar, M.H., \& Abd. Ghani, A.H. (2011). Towards achieving the quality of life in the management of zakat distribution to the rightful recipients (the poor and needy). International

Journal of Business and Social Sciences, 2(4), 237 - 245

Adebayo, R.I. (2011). Zakat and poverty alleviation: A lesson for the fiscal policy makers in Nigeria. Journal of Islamic Economics, Banking and Finance, 7(4), 25 42

Ahmed, H. (2004). Roles of Zakat and waqf in poverty alleviation. Jeddah: 
Islamic Research and Training Institute, Islamic Development Bank.

Al-Qardawi, Y. (1999). Fiqh-az-Zakat (Vol II): A comparative study of Zakat Regulations and philosophy in the light of Qur'an and Sunnah. (M. Kahf, trans.). Saudi Arabia: Scientific publishing centre.

Ammani, S.A., Abbas, S.A., \& Dandago, K.I. (2014). Zakat on employment income in Muslim majority states of Nigeria: any cause for alarm? In proceedings of the International conference on accounting studies, 2014, ICAS. Kuala Lumpur, Malaysia, $305-314$.

Ashafa, S.A. (2014). The administration of Zakat in Lagos and Ogun states. Research on Humanities and Social sciences, 4(21), $74-87$.

Benthall (1999). Financial worship: The Qur'anic injunction to almsgiving. The Journal of the Royal Anthropological Institute, 5(1) 27 42.

Bonner, M. (2003). Poverty and Charity in the rise of Islam. In Poverty and Charity in Middle Eastern Contexts. (pp. 13-30). State University of New York Press.

Bricki, N., \& Green, J. (2007). A guide to using qualitative research methodology. Retrieved from http://hdl.handle.net/10144/84230.

Creswell, J.W. (1984). Research design: qualitative \& quantitative approaches. Thousand oaks, CA: Sage.

Creswell, J.W. (2013). Qualitative inquiry \& research design: choosing among five approaches ( $3^{\text {rd }} \mathrm{Ed}$.). Thousand oaks, CA: Sage.

Creswell, J.W. (2014). Research design: qualitative, quantitative \& mixed method approaches ( $4^{\text {th }}$ Ed.). Thousand oaks, CA: Sage.

De Zayas, G.F. (2003). The law and institution of zakat. (A.Z. Abbasi,
Ed). Kuala Lumpur: The Other Press.

Dogorawa, A.B. (2009). A case for the Muslim ummah in Ghana Poverty alleviation through Zakat and waqf institutions. Paper presented at the First National Muslim Summit, Ghana.

Gillham B. (2005). Research interviewing: The range of techniques. England: Open University Press.

Islahi, A.A. (1993). Islamic distributive scheme: A concise statement. In Alvi, S., \& Al- Roubaie, A. (eds). (2014). Islamic Economics, IV. New York: Routledge. 289-299.

Kochuyt, T. (2009). God, gifts and the poor people: On charity in Islam. Social Compass,56(1),98-116.

Korayem, K., \& Mashhour, N. (2014). Poverty in secular and Islamic economics: conceptualization and poverty alleviation policy, with reference to Egypt. Topics in Middle Eastern and African Economies, 16(1), 1-16.

Latief, H. (2010). Health provision for the poor, Islamic aid and the rise of charitable clinics in Indonesia. South East Asia Research, 18(3), 503-553.

Lorenz, C. (2013). Informal taxation systems-zakat and ushr in Pakistan as example for the relevance of parallel/semi-public dues. Munich Personal RePEc Archive. Paper no 51138.

Lim, H. (2015). Zakat and social protection: the relationship between socio-religious

CSOs and the government in Indonesia. Journal of Civil Society, 11(1), 79-99.

Marshall, C., \& Rossman, G.B. (1989). Designing qualitative research. Newbury Park, California: Sage.

Mattson, I. (2003). Status-based definitions of need in early Islamic zakat and maintenance laws. In M. Bonner, M. Ener, \& 
A. Singer (Eds.), Poverty and charity in Middle Eastern

contexts (31-51). New

York: State University of New

York Press.

Merriam, S.B. (1988). Case study research in education: a qualitative approach. San Francisco: JosseyBass Publishers.

Nanji, A.A. (1985). Ethics and taxation: The perspective of Islamic tradition. The Journal of Religious Ethics, 13(1), 161 178.

Nurul Husna, H., Hazlina, H., Nur Syuhada, J., \& Rashidah A. (2010). Zakat for asnafs' business by Lembaga Zakat Selangor. Malaysian Accounting Review, Special Issue, 9(2), 123 - 138.

Obaidullah, M. (2016). Revisiting estimation methods of business zakat and related tax incentives. Journal of Islamic Accounting and Business Research, 7(4),349-364.

Olanrewaju, S.Q. (2014). Administration of Islamic law within a modern constitutional framework: Problem and prospects of shari'a in secular Nigeria. Project submitted to the faculty of law, University of Lagos, Nigeria.

Ostien, P., \& Dekker, A. (2010). Sharia and national law in Nigeria. In J.M Otto (ed.) Sharia incorporated: A comparative overview of the legal systems of twelve Muslim countries in past and present. Leiden: Leiden University Press.

Ram, A.S., \& Roszaini, H. (2014). Determinants of Zakat (Islamic tax) compliance behaviour. Journal of Islamic Accounting and Business Research, 5(2), 182 $-193$.

Richards, L., \& Morse, J.M. (2013). Read me first for a user's guide to qualitative methods ( $3^{\text {rd }}$ Ed.). Thousand Oaks, CA: Sage.

Rose, A. (2010). Zakat management in Brunei Darussalam: A case study. In the proceedings of the seventh international conference- The Tawhidi epistemology: zakat and waqf economy, Bangi. 375-407.

Salim, D. (2014). The politics of piety in Indonesian democracy: A study on implementation of zakat in West Sumatra. International Indonesia Forum, 2014, Working Paper series 6.

Samad, A., \& Glenn, L.M. (2010). Development of Zakat and Zakat coverage in monotheistic faith. International Journal of social Economics, 37 (4), 302 - 315.

Shirazi, N.S. (1996). Targeting, coverage and distribution of zakat to households' income: The case of Pakistan. Journal of Economic Cooperation Among Islamic Countries, 17, (3-4) 165 - 186.

Singer, A. (2013). Giving practices in Islamic societies. Social Research, 80(2), 341-358.

Suhaib, A. (2009). Contribution of zakat in the social development of Pakistan. Pakistan Journal of Social Sciences, 29(2), 313-334.

Toor, I.A., \& Nasar, A. (2001). Zakat as a social safety net: Exploring the impact. Interim Poverty Reduction Strategy Paper: Government of Pakistan.

Yin, R.K. (2011). Qualitative research from start to finish. New York: The Guildford Press.

Yusuf S.M. (1990). The consumption and distribution of wealth. Economic justice in Islam. Islamabad: Dawah Academy 55-70.

Zainol, B., Kamil, M. I. \& Faridahwati, M. S. (2009). Predicting compliance intention on Zakat on employment income in Malaysia: an application of reasoned action theory. Jurnal Pengurusan, 28, 85-102. 
ZFA. (2007). The Zakat Foundation of America

Adamu Ummulkhayr

Departement of Islamic Studies

School of Arts and Social Sciences

Kogi State College of Education

Nigeria

Musa Yusuf Owoyemi

Universiti Utara Malaysia

Malaysia

Rafidah Binti Mohammed Cusairi

Universiti Utara Malaysia

Malaysia 